\title{
Observations Regarding the Structure of the Parotid and Mandibular Glands in Rabbit
}

\author{
Bianca MATOSZ ${ }^{1}$, Flavia RUXANDA ${ }^{1 *}$, Vasile RUS ${ }^{1}$, Viorel MICLĂUŞ ${ }^{1}$ \\ ${ }^{1}$ University of Agricultural Sciences and Veterinary Medicine Cluj-Napoca, Romania \\ *corresponding author: flavia.ruxanda@gmail.com
}

Bulletin UASVM Veterinary Medicine 73(2) / 2016,

Print ISSN 1843-5270; Electronic ISSN 1843-5378

DOI:10.15835/buasvmcn-vm: 12193

\begin{abstract}
Our study aims to investigate the histological structure of two major salivary glands in adult rabbit. We used 5 adult rabbits, 3 males and 2 females, from a private breeder in Cluj. We harvested the salivary glands, fixed them in $10 \%$ buffered formalin, dehydrated in ethanol (increasing concentration), clarified in n-butanol and embedded in paraffin. The sections (5 $\mu \mathrm{m}$ thickness) were stained with Goldner's trichrome method and examined with an Olympus BX41 light microscope. Histologically, parotid gland in rabbit contains only one type of acini, which presents morphological characteristics of serous acini. In mandibular gland, the acini are all the same, similar to the ones in parotid gland. Concerning the general aspect and dimension they are much larger and polymorphic.
\end{abstract}

Keywords: acinus, mandibular, parotid, rabbit.

\section{INTRODUCTION}

Salivary glands are classified in major and minor. Asfor secretion type, itcan be serous, mucous or sero-mucous (mixed). These distribution types differ from species to species. Thus, in herbivores, salivary secretion adapts to dry food, being mostly serous, in carnivores the secretion is predominant mucous and in omnivores it varies widely. Major salivary glands' structure differs from one species to another, being in relation with the type of food (Al-Saffar and Simawy, 2014). In horse, the cellular component of the parotid gland's acini is exclusively serous, and the mandibular gland is mixed, but the serous component prevails. Parotid gland in brown bat (Myotis lucifugus) is seromucous and mandibular gland is mucous. In koala, mandibular gland is serous, same as the parotid gland. In small ruminants (sheep, goat), parotid glands are purely serous, while in dogs they are sero-mucous.

\section{AIMS AND OBJECTIVES}

The purpose of this study is to investigate the structure of two major salivary glands in adult rabbit - parotid and mandibular glands.

\section{MATERIALS AND METHODS}

We used 5 rabbits, approximately 6 months old, 3 males and 2 females, from a private breeder in Cluj, sacrificed by the owner for own consumption. We harvested the parotid and mandibular glands, fixed them in 10\% buffered formalin, dehydrated in ethanol $\left(70^{\circ}, 95^{\circ}\right.$, absolute), clarified in n-butanol and embedded in paraffin. We sectioned the tissue at a $5 \mu \mathrm{m}$ thickness, stained the sections with Goldner's trichrome method and examined them with an Olympus BX41 light microscope.

\section{RESULTS AND DISCUSSION}

In rabbits, parotid gland is a lobulated gland containing a single type of acini, with narrow lumen and moderate polymorphism both in shape and dimensions. Concerning the size, the acini are small and the acinar cells have round nuclei situated in the basal third of the cell. Their cytoplasm has a fine granular aspect. Regarding the general aspect, they highly resemble the serous acini (Fig. 1). The intralobular ducts are not very numerous and have a relatively small caliber.

Mandibular gland has a single type of acini as well, with narrow lumen and pronounced 


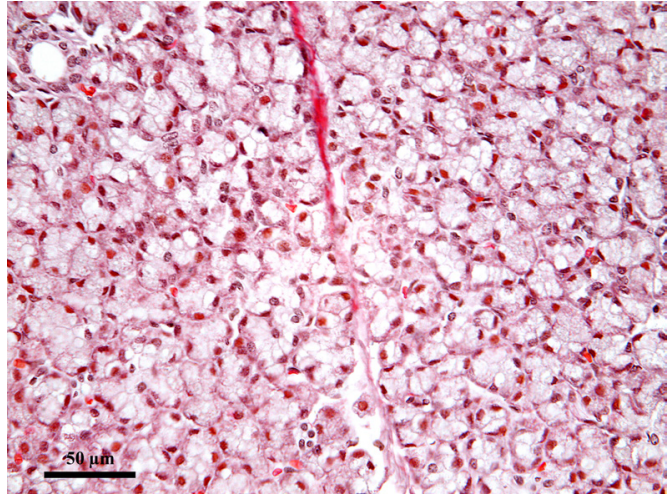

Fig. 1. Parotid gland

polymorphism (Fig. 2). Acinar cells have fine granular cytoplasm. They contain round nuclei, also situated in the basal third of the cell. Regarding their general aspect, the acini from mandibular gland can be classified as serous as well. We can say that they mostly resemble those in parotid gland. The main difference is that in mandibular gland, the acini are obviously larger, with a pronounced polymorphism. Likewise, intralobular excretory ducts are clearly more numerous, with a larger calibre in mandibular gland, in comparison with parotid gland.

Our study reveals the fact that in rabbit, parotid gland has only one type of acini. Regarding the morphological aspect, they highly resemble the serous ones. Similar results were reported by others authors (Al-Saffar and Simawy, 2014). The pure serous character of the parotid gland in rabbit is similar the one in other animal species' parotid gland, such as rat, mouse, goat, sheep, human and rodents, and differs from the one found in dog, cat, ferret, where parotid gland has mixed and serous acini. The acini we found in mandibular gland in rabbit were all the same, and regarding their morphological characteristics they can be classified as serous acini. Even if they resemble morphologically with the ones in parotid gland, they are not identical. Mandibular gland's acini are significantly larger and much more polymorphic. Our results are in accordance with the ones from other authors, who also found that microscopical sections from mandibular gland in rabbit show a larger number of intralobular ducts in comparison with the number in parotid gland (Al-Saffar and Simawy, 2014).

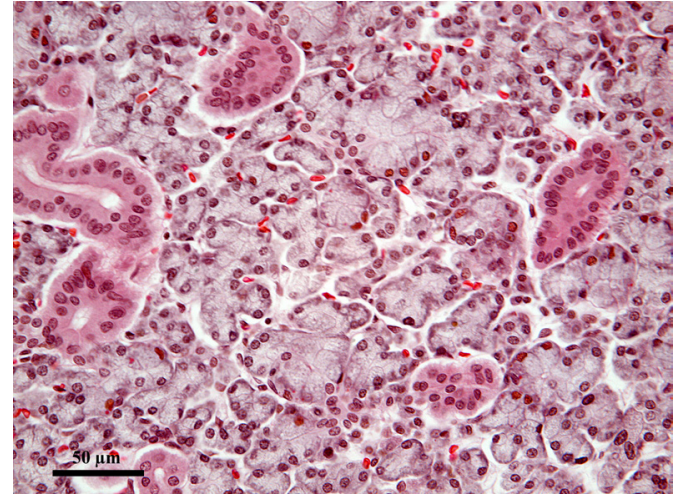

Fig. 2. Mandibular gland

The results we obtained differ from the ones reported by Al-Saffar and Simawy (2014), which affirm that mandibular gland in rabbit is mixed. While mandibular gland is usually formed of mucous acini or a combination of mucous and serous in other mammal species, Mizuno et al. (2009) state that in koala, this gland is serous. Structurally, mandibular gland is similar to the parotid one in this species. Instead, we found that mandibular and parotid glands in rabbit are similar regarding both their histoarchitecture and type of acini. Both glands contain serous acini. Likewise, we found (in previous studies) that this aspect is also seen in chinchilla ((Matosz et al., 2016).

\section{CONCLUSION}

In rabbit, parotid and mandibular glands resemble one another regarding their histoarchitecture and type of acini, which are serous in both glands. The main difference between them is the fact that the acini from mandibular gland are considerably larger and much more polymorphic.

\section{REFERENCES}

1. Al-Saffar FJ, Simawy MSH (2014). Histomorphological and histochemical study of the major salivary glands of adult local rabbits. Intern J Adv Res 2(11): 378-402.

2. Matosz B, Damian A, Rus V, Martonos C, Gal A, Ruxanda F, Miclăuş V (2016). Observations regarding the structure of the major salivary glands in chinchilla. Bulletin UASVM Veterinary Medicine 73(1):111-115.

3. Mizuno T, McKinnon A, Ichihara N, Amasaki T, Asari M, Nishita T, Oishi M, Soeta S, Amasaki H (2009). Histological structure and distribution of carbonic anhydrase isozymes (CA-I, II, III and VI) in major salivary glands in koalas. Anat Histol Embryol 38, 449-454. 